\section{Dynamic collimetorの理論的考察}

札幌医科大学附属病院放射線部 舘岡邦彦，才川峘彦 【目的】Dynamic Wedgeに代表されるようにDynamic collimetor は光子の一次線量をコリメーターの運動により制御するため現在 の固定された照射野での一次線，散乱線の線量測定理論では著し く異なる。そこでDynamic collimetorの線量測定理論を検討し方 法を確立する

【方法】線量にかかわる因子を一次線と散乱線に分離しDynamic collimetorでの，線量因子を空間周波数領域で取り扱い，任意の測 定点での線量の方程式を導く.

【結果】今回，求めた方程式と実測值が良い相関が得られた。

\section{Radiosurgeryにおける線量分布評価}

旭川医科大学医学部附属病院○西部茂美, 平田良昭

現在多くの施設で行われている，Radiosurgeryに用いられる高 エネルギーX線のNarrow Beamsに対する線量評価は、1994年に 日本医学放射線物理学会测定委員会からマニュアルが刊行され、 まだまだ多くの問題点はあるものの，データ取得のための一つの 方向性が示されたわけである．当院においても平成7年3月Varian 社製のClinac2100c及びCAD-PLANが導入され，特にこの装置は X線エネルギー10MVと4MVのデュアルで照射することができ，光 エネルギー並びに照射方法の違いによる容積線量分布の評価を行 ったので報告する。

\section{座長集約 CT-I(20～24)}

座長 市立函館病院 真壁武司 本セッションは、すべて蜾旋CTに関する研究で装置及びソフト ウエアの物理特性が報告された。演題21，22は共に3DCTAにお ける描出能に関する研究で, 演題20では狭窄病変における造影効 果をファントムを用いて評価したところ，CTA単独では空間分解 能に限界があるため評価にはMIP像やDSAとの比較が必要である としていた。 また，演題21は頭部の3DCTAの形状再現性を各種 条件の違いによってファントムを撮影し問題点を明確にした。演 題22は、Helical scanとSingle scan 及びDynamic scanの被曝線 量を比較したものでHelical scanの方がconventional scanに比べ 少なく、この原因としてX線のon，off時にデータ収集に関与しな いメ線が存在することを実測データをもって証明した。

質問. 座長 装置のフィルタやコリメーションの方法によって 被曝線量は違ってくるのでは。

答. Helicalを行った場合スライス厚が薄いほど被曝が多い。 た、フィルタはCuを使用しており線質を硬くすることで中心部と 周囲の差を少なくする様にしている。演題23は、まだ確立してい ない䗎旋CTの性能評価法を第2次勧告ファントムと国立がんセン ターで提唱している方法で行っていたが、測定項目の中には評価 が不十分なものもあり今後の研究に期待したい。

質問. 宮下(耳鼻咽喉科森布病院) 1 coin法で測定した時テーブ ル移動でピークプロファイルがずれた原因は2 Helical scanと Conventional scanで空間分解能に差がでなかったのは何故か。

答. (1Partial volume効果の影警とHelical dataの収集方法に原因 があるのではこファントムの材質と評価方法に問題があった，演 題24は, Beam hardning等によるartfact軽滅のためのBHCについて 自作ファントムを用いて物理評価を行った結果，CT值のsiftが改善 されBHCを使用した方が良好な画像が得られるとしていた。

最後に，今大会では討論室が設けられ演者，質問者によって活 発な論議が行われた. CTの物理特性を知ることで盬床上有用な画 像も提供できるので今後もこの様な場へ会員の積極的参加を期待 したいと思います。

\section{0 䫓部3D-CTAにおける狭窄病変の描出能と造影効果 \\ 医療法人札幌麻生脳神経外科病院}

○大森 恒, 小寺秀一。安井一久

頚部血管狭窄を想定した模擬血管ファントムを用いて、造影効果 の違いがもたらす狭窄の描出能の良否について検討した。

【方法 1】模擬血管径の違いによるCT值の変化、及び再構成関 数の違いによるCT値の变化について.

【方法2】模擬血管內のCT値を変化させへリカルスキャンを行い3D イメージを作成し, 各血管径におけるCT值と闘値の関係について 【結果】ⒸT值が高い物の方が模擬血管径が細くなるにしたがい CT値の低下が顕著であった。司模擬血管径 $1.1 \mathrm{~mm}$ 以下の場合そ れ以上の径とでは閶值の範囲が重ならず単一の闘值で正確に表現 することは困難であった。(3.実際の臨床例においては $1.2 \mathrm{~mm}$ 径の 狭窄部位は単一の閵值で表現する事が出来たが，0.9mm径の狭窄
部位は描出する事が出来なかった。

\section{1 頭部3D-CTAにおける形状再現性の基礎的検討}

医療法人札幌柇生脳神経外科病院

氺寺秀一，大森 峘，安井一久

頭部3D-CTAにおいて，血管の形状再現性は，造影手技の違い や患者個々の造影効果の差異，また、様々なScan条件の違いによ bAxial-imageの分解能やSD值が変化し，大きく影隌を受ける。 今回我々は，実際の人体頭部をScanした時と同等の状態を自作つ ァントムで出来るだけ再現し，样々な条件下での血管形状再現性 について検討した。その結果，形状再現性の良い高精度の頭部 3D-CTAを得るための条件は，(1)薄いスライスで遅いテーブル移 動，(2)小さいFOVで縕かい再構成間隔，(3)空間分解能と低ノィ ズを両立した再構成関数、(4)高電圧で、高線量、(5)高い閶值処 理が可能な造影手技であると言うことが出来た。

\section{2 ヘリカルスキャンCT被䀧線量に関する一考察}

福島県立医科大学附属病院 放射線部

○遊佐 烈，片倉俊彦，鈴木憲二，清野真也，村上克彦 佐藤勝正，伊藤陸郎

ヘリカルスキャンの被曝線量は少ないと言われているが，少な くなる原因の検討は十分とは言えない，今回コンベンショナルス キャンとへリカルスキャンの被曝線量を比較し、被曝線量の差が 生ずる原因について検討した。結果，コンベンショナルスキャン は線量が多く，ファントムの中心よりも周辺の線量の差が大きく なった。これは，モーションアーティファクト対策としてオーバ ーラップスキャンが行わ机，ダイナミックスキャンやへリカルス キャンに比べ，一回転につき10\%線量が多くなる．更に、線管 電流波形より，スイッチのON，OFF時の立ち上がり，立ち下が り部分に、画像に関与しない低エネルギーの線が存在し、6〜10 \%線量が多くなる。

\section{Hispeed Advantage RPの性能評価}

NTT札幌病院放射線科 ○桑原貞俊，川原聖樹

【目的及び方法】CT性能評価委員会の第 2 次勧告に挙げられて いる項目のうち数項目を選択し測定するとともに、管電圧及び寸 法依存性・ヘリカルスキャン使用時の性能等に関しても検討し， 最適な撮影条件を選択することを試みた。

【結論】140kVを使用することにより，管球負荷を軽滅しS/Nお よび分解能も向上するがC下值の直線性などに問題が生じる。 MTFより, Lung関数は他の高分解能関数に比べ，低周波が著しく 低くなるためthin sliceには使用できない。

ヘリカルスキャンに関しヘリカルCTファントムを使用したが、 その方法・形状・取り扱い易さも含めさらに改良されることを望 む。また、各項目に関し更なる検討を重ねたい、

\section{4 高速スキャンにおけるBHC処理の評価}

医療法人耳廙咽喉科麻生病院

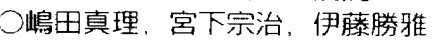

(株) 東芝医療機器第2技術部CTシステム小川幸宏

【目的】軟部組織を目的とする関心エリアの中に高いCT值(骨)が 存在するとき、ビームハードニングァーチファクトが発生するこ とは広く知られている，その対策のために開発されたBHC(Beam Hardning Correction)に対し，ファントムを試作し，その有効性 について検討した。

【方法】水ファントムにアルミリングをかぶせたもの，内部にア ルミ円柱を入れたもののふたつのファントムを試作した。ファン トムをスキャンし、視覚的、CT值、プロファイルカーブ等で比較 検討した。

【結果】BHC補正処理関数の画像はCT值のシフトが明らかに改 善した。ファントムを制作，使用したことにより，簡便に評価す る事ができた。

座長集的 CT- II (25 28)

座長 小寺秀一 札幌麻生脑神経外科病院 本セッションは、CTの臨床応用についての演題が 4 題出され た. ヘリカルCTが登場して以来、検查手技も多岐にわたり，さま ざまな臨床応用が報告され，その有用性、可能性はさらに広がり つつある。

25席はそんな中にあって，従来型のCTによる脳の日常検查にお いて, 超急性期脳梗塞の症例で，中大脳動脈の血恮と思われる高 吸収領域を確認でき、日頃の検査の質の向上が重要であるとの報 